\title{
An Early Ceramic Period Pit Feature at the Swan Lake Site (16B011), Bossier Parish, Lousiana
}

Jeffery S. Girard

Northwestern State University of Louisiana

Follow this and additional works at: https://scholarworks.sfasu.edu/ita

Part of the American Material Culture Commons, Archaeological Anthropology Commons, Environmental Studies Commons, Other American Studies Commons, Other Arts and Humanities Commons, Other History of Art, Architecture, and Archaeology Commons, and the United States History Commons

Tell us how this article helped you.

This Article is brought to you for free and open access by the Center for Regional Heritage Research at SFA ScholarWorks. It has been accepted for inclusion in Index of Texas Archaeology: Open Access Gray Literature from the Lone Star State by an authorized editor of SFA ScholarWorks. For more information, please contact cdsscholarworks@sfasu.edu. 


\section{An Early Ceramic Period Pit Feature at the Swan Lake Site (16B011), Bossier Parish, Lousiana}

\section{Creative Commons License}

\section{(c) (1) \&}

This work is licensed under a Creative Commons Attribution-NonCommercial 4.0 International License 


\title{
AN EARLY CERAMIC PERIOD PIT FEATURE AT THE SWAN LAKE SITE (16BO11), BOSSIER PARISH, LOUISIANA
}

\author{
Jeffrey S. Girard \\ Northwestern State University, Natchitoches, Louisiana
}

\section{INTRODUCTION}

A pit feature containing Tchefuncte-like pottery, a Gary point, and faunal remains recently was investigated at the Swan Lake Site (16BO11) located near Willow Chute Bayou in the Red River floodplain of eastern Bossier Parish (Figure 1). Three charcoal samples from the pit yielded radiocarbon ages of $2020+1-60$ B.P., $1830+/-70$ B.P., and $1690+/-80$ B.P. making this the earliest well-dated context in northwestern Louisiana containing ceramics.

The most conspicuous feature at the site is a mound, now approximately $2.5 \mathrm{~m}$ high and about $25 \mathrm{~m}$ in diameter. Clarence Webb first recorded the site, but only made a short description:

"Solitary mound on n-east shore of Swan Lake, which is an old Red River channel. Is circular in shape, approx. 8-10 ft. high, $60 \mathrm{ft}$. at the base and $20 \mathrm{ft}$. on summit.
Has several shallow trial holes on top, appears to be built up of sand -- no sherds found on or around mound -- trial holes show mostly sandy soil near clay out in field. In one or two places 3 to 4 inches dark soil found. In nearby field, 1 rough spear head found." (Webb n.d.)

Since Webb's initial visit the landowners have collected numerous artifacts from the site surface. Most of the decorated pottery consists of Early to Middle Caddoan Period types suggesting that the mound is related to those at the nearby Vanceville (16BO7) and Werner (16BO8) sites. However, also present are a large number of Gary points and several sherds similar to those recovered from the Bellevue Site (16BO4) (Fulton and Webb 1953; Webb 1982) indicating that an earlier occupation is represented as well.

\section{INVESTIGATIONS}

Grasses now cover the site surface and no prehistoric artifacts are visible. During the spring of 1994 Louis Baker (Louisiana Archaeological Society) and I excavated 11 auger tests in the southern portion of the site north of the mound. For the most part, the results were not particularly exciting. We recovered a combined total of four undecorated sherds and one flake, mostly within the upper 20 to $30 \mathrm{~cm}$ of deposit overlying an argillic soil horizon. However, one auger test differed substantially. This test, located approximately $75 \mathrm{~m}$ north of the mound, was excavated to two $m$ below the surface without encountering the argillic horizon. Dark brown loam extended to $1.6 \mathrm{~m}$ below the surface at which point a fine sand was encountered. A 


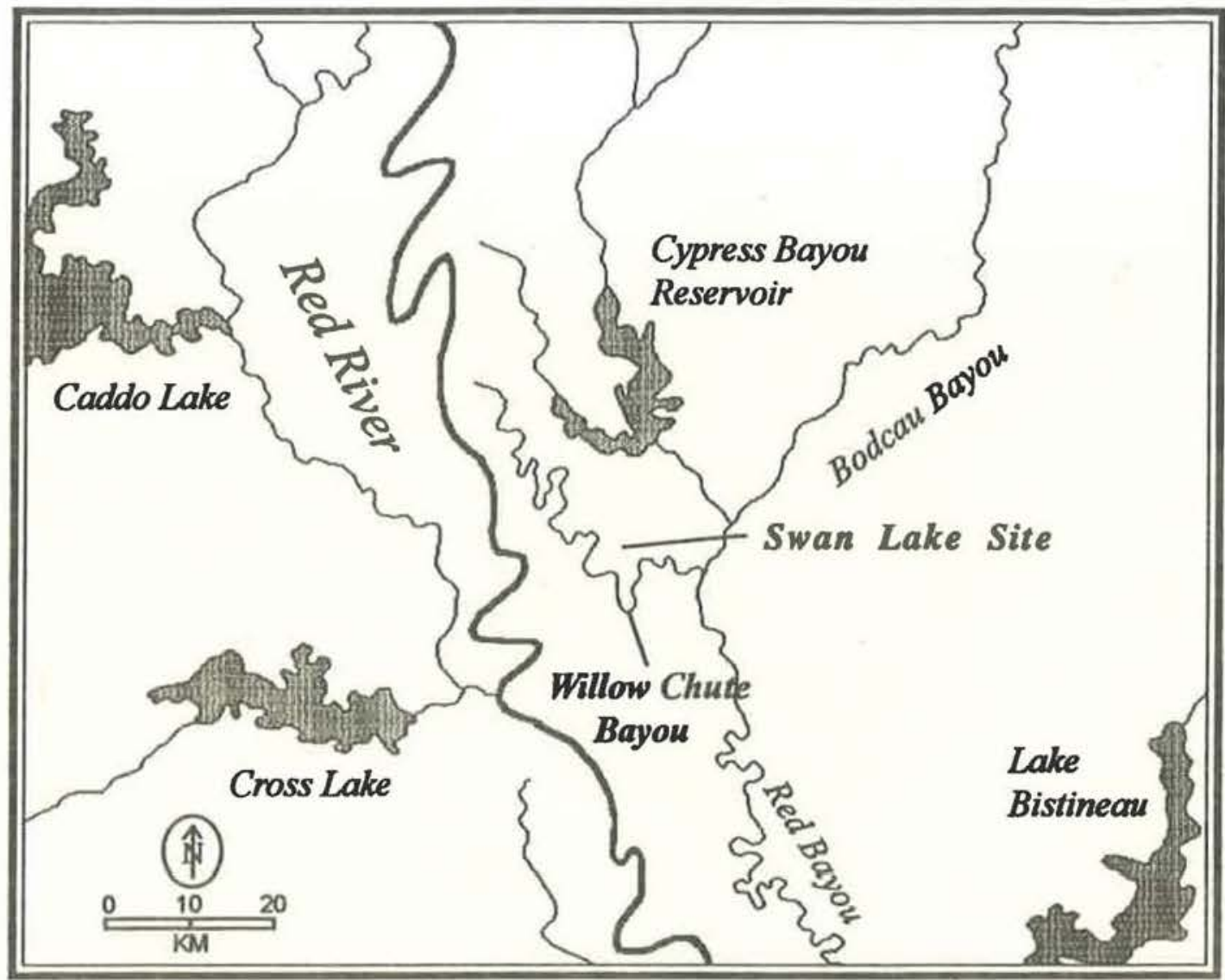

Figure 1. Location of the Swan Lake Site (16C)11).

sherd was recovered between $1.25 \mathrm{~m}$ and $1.35 \mathrm{~m}$ below the surface and numerous lumps of fired clay and charcoal were recovered at approximately $1.4 \mathrm{~m}$.

We opened up five contiguous $1 \times 1 \mathrm{~m}$ units and determined that a pit was present with dimensions of approximately $1.5 \mathrm{~m}$ by $1 \mathrm{~m}$. Because of its large size and our wish to obtain a vertical profile view of the feature, we excavated fill from only the southern half.

Sherds and flakes were recovered down to approximately $1.3 \mathrm{~m}$ below the surface, at which point most of the fill consisted of chunks of poorly fired clay up to $3 \mathrm{~cm}$ in diameter. The chunks continued to the base of the pit which was encountered between 1.5 and $1.6 \mathrm{~m}$ below the surface (Figure 2). Small fragments of charcoal were scattered throughout the lower portions of the pitfill. In the lowest $30 \mathrm{~cm}$ several $3-5 \mathrm{~cm}$ chunks were recovered and retained for radiocarbon analysis. Also present in the fill were small fragments of animal bone. Unfortunately, most of the specimens were too small and soft to retrieve during the excavations. Soil samples were taken from each $10 \mathrm{~cm}$ excavation level for flotation analysis, but only small fragments of charred bone were recovered with fish and turtle being the only identifiable animals represented. 


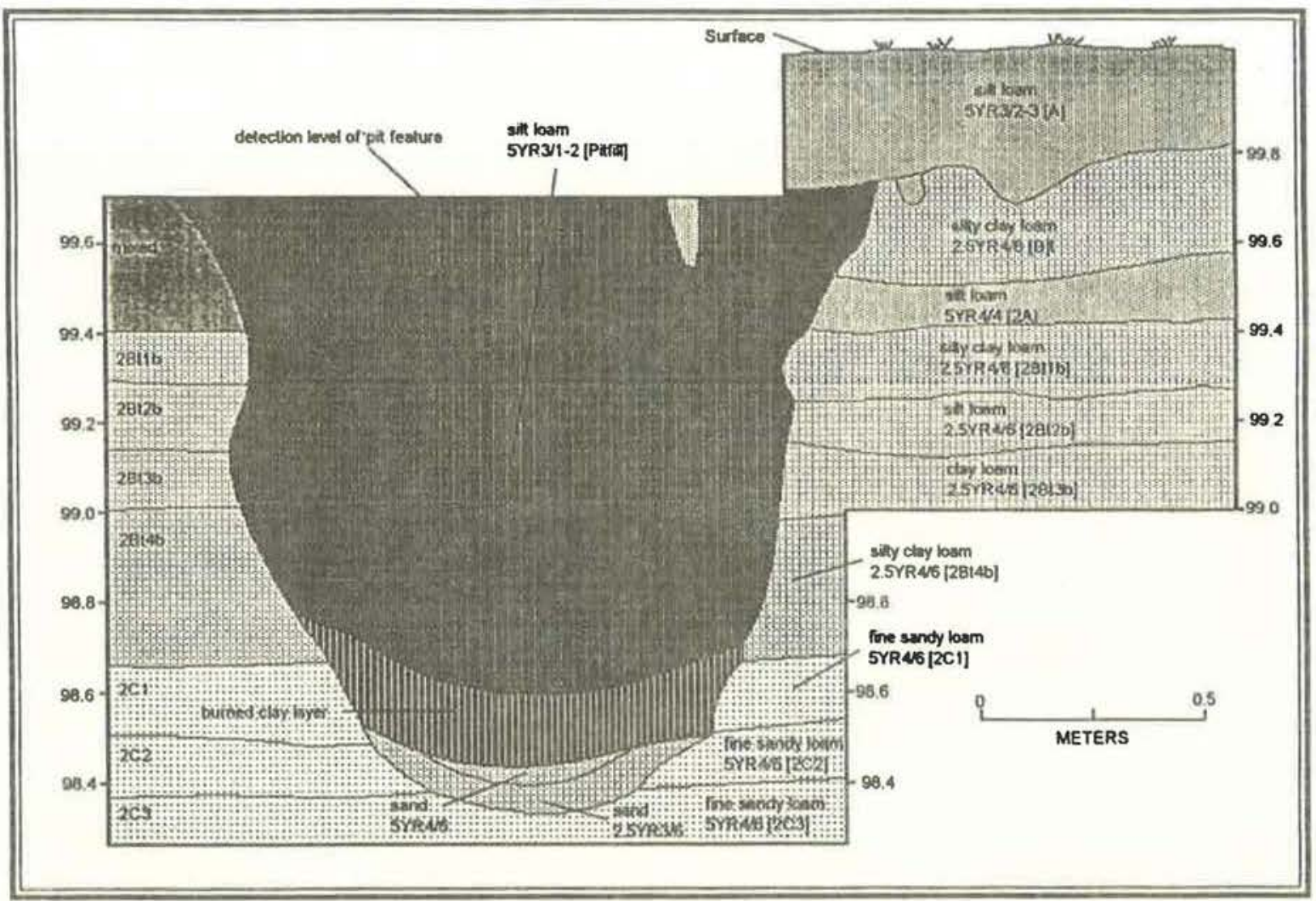

Figure 2. Profile of the Pit Feature at the Swan Lake Site.

The feature appears to have served as a large roasting pit. Burning in situ was indicated by the clay lumps and by reddening of the deposits sur- rounding the lowest $30 \mathrm{~cm}$ of the pit. Following its final use, the pit was filled with sediments that contained habitation debris.

\section{DESCRIPTION OF THE POTTERY}

The pottery recovered from the pit feature differs substantially from that recovered at other sites along Willow Chute Bayou. The paste is soft and crumbles easily. Chunks of clay or grog are numerous and often large. The paste of most sherds is laminated and many specimens have split through the middle (separating the surfaces). Edges of sherds have a ragged appearance suggesting that vessels were not constructed by building coils. The clay appears to be relatively fine-textured although a few speci- mens have a silty or fine sandy feel. Sherd thickness ranges from 7 to $9 \mathrm{~mm}$.

Surfaces are smoothed but are finely crackled or crazed on many specimens. On a few sherds interior surfaces are very well smoothed but none are polished. Surfaces also are uneven and it appears that thinning vessel walls was carried out by pinching or paddling rather than scraping (finishing marks indicative of scraping are absent). 
It is not possible to ascertain much about vessel size and shape. Three relatively large rim sherds suggest that vessel sides slant inward near the lip and a large bowl may be represented. Except for a single sherd recovered between 1.0 and 1.1 $\mathrm{m}$ below the surface that has one incised line, decorations are absent.
In many respects the sherds are similar to Tchefuncte pottery from the lower Mississippi Valley and Gulf Coast, particularly in apparent construction technique. However, abundant clay and grog inclusions contrast with the generally untempered Tchefuncte pottery; similarities to early Baytown Plain varieties(e.g., var. Marksville; Phillips 1970:50-51) also are apparent.

\section{RADIOCARBON ANALYSIS OF THE CHARCOAL SAMPLES}

Three charcoal samples were submitted to Beta Analytic Inc. for radiocarbon analysis (Table 1). Sample 1 was a large chunk of charcoal from the base of the pit, approximately $1.5 \mathrm{~m}$ below the surface. Sample 2 was similar, but recovered in the overlying $(1.4-1.5 \mathrm{~m})$ level. Sample 3 was from scattered charcoal recovered between 1.2 and $1.4 \mathrm{~m}$ below the surface.

A T-test run using the CALIB program of Stuiver and Reimer (1993) indicates that all three samples differ significantly from one another at the 0.95 probability level. Given the absence of distinct strata or lensing, it is difficult to believe that the pit remained open for several hundred years. However, the pit may have been periodically cleaned out and reused over a sufficiently long time span to produce the above results. The Sample 3 age seems least likely to relate to use of the feature given the scattered nature of the charcoal and its location above the area of intensive burning. The average of Samples 1 and 2 was calculated using the CALIB program and the results are included in Table 2 .

Table 1. Radiocarbon Calibrations Using Method A of Suiver and Reimer (1993).

\begin{tabular}{lllll}
\hline \hline $\begin{array}{c}\text { Site } \\
\text { sample }\end{array}$ & $\begin{array}{l}\text { Lab } \\
\text { sample }\end{array}$ & $\begin{array}{c}\text { Conventional } \\
\text { age }\end{array}$ & $\begin{array}{l}\text { One Sigma } \\
\text { Calibration }\end{array}$ & $\begin{array}{l}\text { Two Sigma } \\
\text { Calibration }\end{array}$ \\
\hline $16 \mathrm{BO} 11-1$ & Beta-73339 & $1830 \pm 70 \mathrm{BP}$ & AD119 - AD319 & AD 58 - AD391 \\
$16 \mathrm{BO} 11-2$ & Beta-73340 & $2020 \pm 60 \mathrm{BP}$ & 59BC - AD 67 & $175 \mathrm{BC}-\mathrm{AD} 121$ \\
$16 \mathrm{BO} 11-2$ & Beta-73341 & $1690 \pm 80 \mathrm{BP}$ & AD252 - AD433 & AD145 - AD548 \\
\hline \hline
\end{tabular}

\section{DISCUSSION}

The fill of the pit above the burned clay layer was relatively homogeneous and lacked lensing or stratification that would be indicative of infilling over an extended period of time. I suspect that, shortly after its last use, the pit was backfilled by the site occupants with deposits containing midden debris. Thus, it is likely that the sherds recovered within the fill either predate, or are approximately contemporaneous with, use of the pit. As noted earlier, a few sherds from the site surface are similar to pottery recovered at the Bellevue Mound site (16BO4) 
Table 2. Radiocarbon Calibrations Using Method B of Stuiver and Reimer (1993).

\begin{tabular}{lcccc}
\hline \hline \multirow{2}{*}{ Site Sample } & \multicolumn{2}{l}{ One Sigma Calibration } & \multicolumn{2}{c}{ Two Sigma Calibration } \\
\cline { 2 - 5 } & Range & Probability & Range & Probability \\
\hline 16B011-1 & AD117 - AD258 & 0.87 & AD 62 - AD386 & 1.00 \\
& AD293 - AD321 & 0.12 & & \\
16 B011-2 & 67BC - AD 72 & 1.00 & 168BC - AD 89 & 0.97 \\
& & & AD 92 - AD117 & 0.03 \\
16B011-3 & AD249 - AD438 & 1.00 & AD147 - AD179 & 0.02 \\
& & & AD194 - AD547 & 0.98 \\
Average of & 58BC - AD 82 & 0.53 & 161BC - AD342 & 1.00 \\
Samples 1 and 2 & AD 89 - AD 99 & 0.03 & & \\
& AD115 - AD342 & 0.44 & & \\
\hline \hline
\end{tabular}

located along Bodcau Bayou approximately 15 $\mathrm{km}$ to the northeast. The Bellevue sherds are thinner, harder, and have a siltier paste than those from the pit. Unfortunately, there are no radiocarbon determinations from the Bellevue site or other contexts containing this pottery.

The presence of the pit near the mound at Swan Lake raises questions about the temporal affiliation of the mound. The initial assumption that it relates to a Caddoan occupation may be in error. Although Caddoan ceramics are present at the site, none have come from the moundfill. The landowners report that the only artifact that has eroded from the mound is a large stemmed bi- face of exotic chert, a specimen that resembles those recovered from the Coral Snake Mound (16SA48) in the Sabine River drainage (McClurkan et al. 1966:10; Jensen 1968:80).

The Swan Lake site has the longest span of occupation yet identified in this portion of the Red River floodplain. Although occupations are not stratified by varying depositional strata (a buried soil has been recognized beneath the upper argillic horizon, but contains no evidence of human activity), additional features are likely to be present that should enable us to isolate distinct occupations and address a wide range of research problems.

\section{REFERENCES CITED}

Fulton, Robert L. and Clarence H. Webb 1953 The Bellevue Mound: A Pre-Caddoan Site in Bossier Parish, Louisiana. Texas Archeological and Paleontological Society Bulletin 24:18-42.

Jensen, Harald P. 1968 Archeological Excavations in the Toledo Bend Reservoir: 1966-1967. Report submitted to the National Park Service. Archaeology Salvage Project, Southern Methodist University. Dallas, Texas.

McClurkan, Burney B., William T. Field, and J. Ned Woodall

1966 Excanations in Toledo Bend Reservoir, 1964-1965. Papers of the Texas Archeological Salvage Project No. 8, Austin. 
Phillips, Phillip

1970 Archaeological Survey in the Lower Yazoo

Basin, Mississippi, 1949-1955. Papers of the Peabody Museum, Harvard University, Vol. 60, Cambridge.

Stuiver, Minze, and Paula R. Reimer 1993 Extended ${ }^{14} \mathrm{C}$ Database and Revised CALIB Radiocarbon Calibration Program. Radiocarbon 28:1022-1030.

\section{Webb, Clarence $\mathrm{H}$.}

1982 The Bellevue Focus: A Marksville-Troyville Manifestation in Northwestern Louisiana. In The Troyville-Baytown Period in Lower Mississippi Valley Prehistory: A Memorial to Robert Stewart Neizzel, edited by J.L. Gibson, pp. 251-274. Louisiana Archaeology 9.

n.d. Original unpublished notes concerning archaeological sites in Louisiana. Ms. on file, Northwestern State University, Natchitoches.

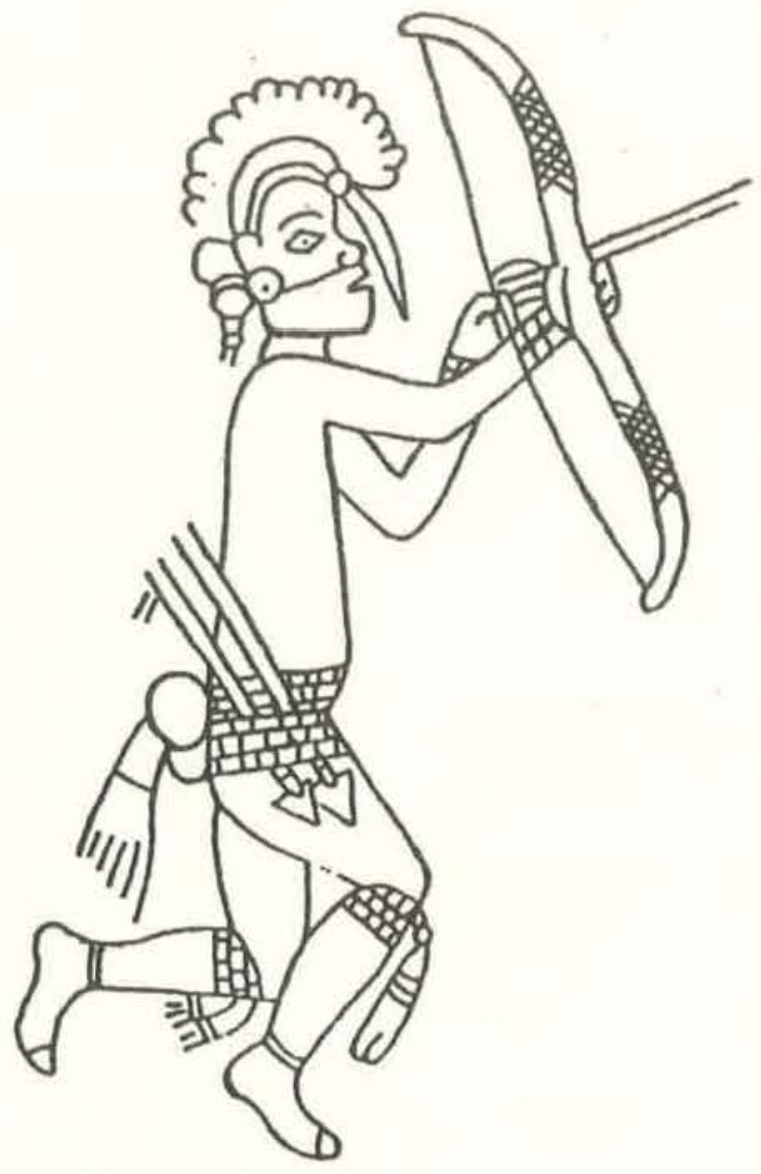

